\title{
AMYLASE PRODUCTION BY ENDOPHYTIC FUNGI CYLINDROCEPHALUM SP. ISOLATED FROM MEDICINAL PLANT ALPINIA CALCARATA (HAW.) ROSCOE
}

\author{
Sunitha. V. H., Ramesha. A., Savitha. J., Srinivas. C*
}

Department of Microbiology \& Biotechnology, Jnanabharathi Campus, Bangalore University, Bangalore- 560056.

Submitted: August 19, 2011; Returned to authors for corrections: October 25, 2011; Approved: June 07, 2012.

\begin{abstract}
Amylases are among the most important enzymes used in modern biotechnology particularly in the process involving starch hydrolysis. Fungal amylase has large applications in food and pharmaceutical industries. Considering these facts, endophytic fungi isolated from the plant Alpinia calcarata (Haw.) Roscoe were screened for amylolytic activity on glucose yeast extract peptone agar (GYP) medium. Among thirty isolates of endophytic fungi, isolate number seven identified as Cylindrocephalum sp. (Ac-7) showed highest amylolytic activity and was taken for further study. Influence of various physical and chemical factors such as $\mathrm{pH}$, temperature, carbon and nitrogen sources on amylase production in liquid media were studied. The maximal amylase production was found to be at $30^{\circ} \mathrm{C}$ and at $\mathrm{pH} 7.0$ of the growth medium. Among the various carbon and nitrogen sources tested, maltose at $1.5 \%$ and Sodium nitrate at $0.3 \%$ respectively gave optimum amylase production.
\end{abstract}

Key words: Alpinia calcarata Roscoe; Endophytic fungi; Cylindrocephalum sp.; Amylase.

\section{INTRODUCTION}

Amylases are one of the most important industrial enzymes that have a wide variety of applications ranging from conversion of starch to sugar syrups, to the production of cyclodextrins for the pharmaceutical industry. Fungal amylases have been widely used for the industrial production due to advantages such as cost effectiveness, consistency, less time and space required for production and ease of process modification and optimization (6). These enzymes account for about $30 \%$ of the world's enzyme production (40). Amylases are starch degrading enzymes that catalyze the hydrolysis of internal glycosidic bonds in polysaccharides with the retention of anomeric configuration in the products. Most of the amylases are metalloenzymes, which require calcium ions $\left(\mathrm{Ca}^{2+}\right)$ for their activity, structural integrity and stability (5). Amongst starch degrading enzymes are endo-amylases, exoamylases, debranching enzymes and glycosyltransferases (21). The enzymatic hydrolysis is preferred to acid hydrolysis in starch processing industry due to specificity of the reaction, stability of the generated products, lower energy requirements and elimination of neutralization steps (36). Because of the increasing demand for these enzymes in various industries, there is enormous interest in developing enzymes with better properties such as raw starch degrading amylases, which are suitable for industrial applications and their cost effective 
production techniques.

Most of the amylases have been produced from soil fungi such as Aspergillus, Penicillum and Rhizopus (31). Very few reports are available on amylases from endophytic fungi, which are mainly explored for beneficial secondary metabolites with different bioactivity (25). Endophytic fungi usually live asymptomatically within tissues of their host plants protecting them from natural enemies (10). Caldwell et al., (7) reported the ability of dark septate root endophytic fungi, Philaophora finlandia and $P$. fortinii isolated from Alpine plant communities, which were able to breakdown the major polymeric forms of carbon, nitrogen and phosphorus found in plants. Marlida et al., (26) reported raw starch degrading enzyme from endophytic fungi Gibberella pulicaris, Acremonium sp. Synnematous sp. and Nodilusporium sp. Maria et al., (24) also reported amylase production by few endophytic isolates from mangrove angiosperm Acanthus ilicifolius L. and mangrove fern, Acrostichum aureum L. There are no reports of amylase production from endophytic fungi isolated from Alpinia calcarata. This led us to explore the amylolytic potential of the endophytic fungi isolated from this plant.

The aim of the present study was to screen the different endophytic fungi for amylase production isolated from $A$. calcarata and study the capability of hydrolyzing a wide range of cheap and easily available starch source as substrates.

\section{MATERIALS AND METHODS}

\section{Sources of endophytic fungi}

Endophytic fungi were isolated from fresh material of healthy wild medicinal plant Alpinia calcarata Roscoe, which belongs to the family Zingiberaceae collected from the Charaka Sushrutha Vana, situated in Jnanabharathi Campus, Bangalore University, Bangalore, India. The Charaka Sushrutha Vana consists of five hundred medicinal plants grouped into fifty, based on their treatment to ailments, each group comprising of ten plants. These plants are planted in three concentric circles, the inner circle consisting of ten plants, outer circle consisting of twenty plants and the outermost circle with twenty. The medicinal garden is maintained by Sri Adichunchangiri Shikshana trust, Sri Kalabhairaveshwara Swamy Medical College, Hospital and Research Centre, Vijayanagara, Bangalore, India.

\section{Isolation \& identification of the endophytic fungi}

The endophytic fungal strains were isolated from the medicinal plant $A$. calcarata Roscoe. The plant samples along with flowers and leaves were deposited for herbarium (RRCBIMus/09) and authenticated by National Ayurveda Dietetics Research Institute (Central Council for Research in Ayurveda and Siddha), Department of AYUSH, Ministry of Health and Family Welfare, Govt. of India, (New Delhi) Jayanagar, Bangalore, India.

Different parts of the $A$. calcarata such as leaves, midrib, petiole and stem were cut with the help of knife disinfected with $70 \%$ ethanol and brought to the laboratory. The collected samples were washed with tap water, cut into $0.5 \mathrm{~cm}^{2}$ segments and were surface sterilized with standard triple ethanol-sodium hypochlorite-ethanol (16). Fifteen segments from each individual plant parts were placed in Petri plate containing Potato dextrose agar (PDA; HiMedia), autoclaved at $121^{\circ} \mathrm{C}$, $15 \mathrm{lbs}$ for 15 minutes and amended with tetracycline (150 $\left.\mathrm{mgL}^{-1}\right)$. The Petri plates were then sealed with cellophane tape and incubated in a light chamber at $28^{\circ} \mathrm{C}$ with $12 \mathrm{hrs}$ light followed by 12 hrs darkness. Regular observation of the Petri plates was done from the second day onwards for a period of 3-4 weeks for the fungal colonies (4). The fungi growing from internal tissues were transferred to fresh PDA slants and stored at $4^{\circ} \mathrm{C}$. The fungi were identified based on the cultural, morphological characteristics of the fruiting bodies and spores using standard manuals $(3,15,38)$.

\section{Taxonomic identification of the fungus}

The colonies were effuse, grey or olivaceous measuring 
about $6-7 \mathrm{~cm}$ in 7 days on PDA. Mycelium hyaline, conidiophores were mononematous, short $(20-30 \mu \mathrm{m})$, cylindrical and pointed at the apex, arising from aerial hyphae. Conidia were one celled, hyaline, ellipsoid (11-14 x 1.2. -2.5 $\mu \mathrm{m})$ produced successively at the apex of the conidiophore and held together in loose clusters. The fungus was identified as Cylindrocephalum sp. (3).

\section{Screening of endophytic fungi for amylase production on solid media}

Endophytic fungal culture grown on PDA was cut into 5 $\mathrm{mm}$ discs with the help of borer. Three discs were placed on Petri plate containing autoclaved $15 \mathrm{~mL}$ of glucose yeast extract peptone agar (GYP) medium (glucose $1 \mathrm{~g}$, yeast extract $0.1 \mathrm{~g}$, peptone $0.5 \mathrm{~g}$, agar $16 \mathrm{~g}$ and distilled water $1000 \mathrm{~mL}$ ) with $0.2 \%$ soluble starch at $\mathrm{pH}$ 6.0. (20). After incubation, the plates were flooded with $1 \%$ iodine solution in $2 \%$ Potassium iodide. Zone of clearance around the colony was measured (24).

\section{Optimization of culture conditions for amylase production}

The procedure adopted for optimization of various parameters influencing amylase production was to evaluate the effect of each parameter independently keeping others as constant. The optimized parameters were incorporated in subsequent experiments. All experiments were done in triplicate and the mean values are presented.

Out of thirty isolates, eleven of them showed positive for Iodine test on solid media. Among these, the isolate number 7 of A. calcarata identified as Cylindrocephalum sp. (Ac-7) which gave maximum activity was selected for the optimization of amylase activity in liquid media. The organism was grown in $25 \mathrm{~mL}$ of basal media $\mathrm{g} / \mathrm{L}\left(\mathrm{NaNO}_{3} 3 \mathrm{~g}\right.$, $\mathrm{MgSO}_{4} .7 \mathrm{H}_{2} \mathrm{O} 0.5 \mathrm{~g}, \mathrm{KCl} 5 \mathrm{~g}, \mathrm{KH}_{2} \mathrm{PO}_{4} 1 \mathrm{~g}, \mathrm{FeSO}_{4} .7 \mathrm{H}_{2} \mathrm{O} 0.01 \mathrm{~g}$, $\mathrm{CaCl}_{2} 0.1 \mathrm{~g}$ ) and supplemented with $1.5 \%$ starch in $150 \mathrm{~mL}$ Erlenmeyer flasks and autoclaved at $121^{\circ} \mathrm{C}, 15 \mathrm{lbs}$ for 15 minutes. After sterilization, the flasks were cooled to room temperature and $0.1 \mathrm{~mL}$ spore suspension of the fungal strain was inoculated and incubated for 7 days at different parameters as described below by taking one parameter at a time. An uninoculated flask served as control.

\section{Effect of temperature, $\mathrm{pH}$, carbon and nitrogen sources on} Amylase activity

Present study was carried out at different temperature (15, 25, 30, 37 and $\left.45^{\circ} \mathrm{C}\right)$ and $\mathrm{pH}(3,5,7,9$ and 11). Different sources of carbon such as corn flour (COF), cassava flour $(\mathrm{CAF})$, rice bran powder (RBP), wheat bran powder (WBP), maltose (MAL), starch (STR) at $1.5 \%(\mathrm{w} / \mathrm{v})$ and Nitrogen sources, peptone (PEP), tryptone (TRP), beef extract (BE), yeast extract (YE), ammonium nitrate (AN) and sodium nitrate $(\mathrm{SN})$ at $0.3 \%(\mathrm{w} / \mathrm{v})$ were used to determine their effect on the production of amylase activity.

\section{Determination of fungal biomass}

The biomass of fungal culture was expressed as dry weight by drying the mycelium in hot air oven at $80^{\circ} \mathrm{C}$ for $16 \mathrm{~h}$.

\section{Enzyme assay}

The culture broth was filtered using Whatman filter paper No.1, the filtrate was centrifuged at $2795 \mathrm{~g}$ for 10 minutes at $4^{\circ}$ $\mathrm{C}$ and the supernatant was used for enzyme assay. Amylase activity was determined at room temperature in a reaction mixture containing $1 \mathrm{~mL}$ of $1 \mathrm{~mol} \mathrm{~L}^{-1}$ sodium acetate buffer $(\mathrm{pH}$ $6.0), 0.5 \mathrm{~mL} 1 \%$ starch (w/v) and $0.5 \mathrm{~mL}$ of the crude enzyme extract (20). After 20 minutes of incubation, the liberated maltose was estimated by dinitrosalicylic acid (DNS) method (27). One unit of amylase activity (U) is defined as the amount of enzyme releasing one $\mu \mathrm{mol}$ of reducing sugar $\mathrm{mL}^{-1} \mathrm{~min}^{-1}$, with maltose as standard under the assay conditions mentioned above. The denatured culture filtrate served as control.

\section{Statistical analysis}

Analysis of Variance was conducted by ONE-WAY ANOVA test using SPSS 16.0 from MICROSOFT WINDOWS and the means of the triplicates were compared by Duncan's multiple range test (13) at the 0.05 level of significance. 


\section{RESULTS AND DISCUSSION}

\section{Screening of endophytic fungi for amylase production on solid media}

Out of thirty endophytic isolates screened for the amylolytic activity on solid media, eleven of them showed positive results. Among these the isolate (Ac-7) Cylindrocephalum sp., which showed maximum zone of clearance, was selected for the optimization of amylase activity in liquid media. Mean results are represented in Fig. 1.

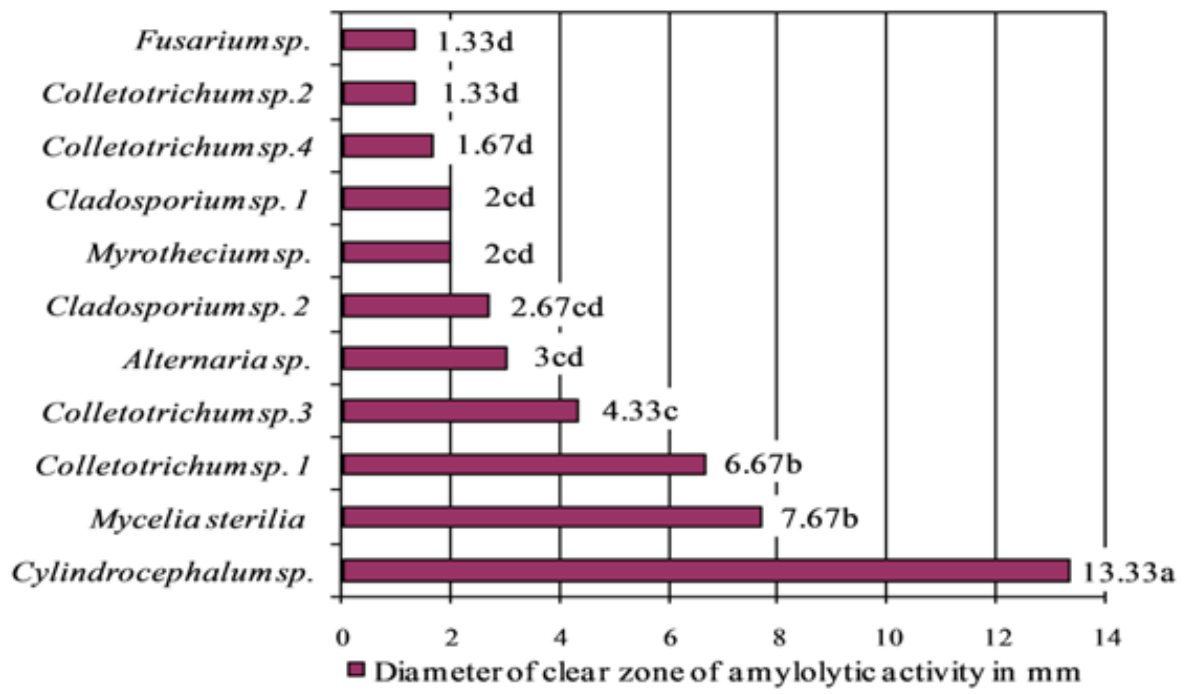

Figure 1. Amylolytic activity of endophytic fungi

\section{Optimization studies}

Optimization of various parameters and manipulation of media are one of the most important techniques used for the production of enzymes in large quantities to meet industrial demands (39). Production of amylase enzyme in fungi is known to depend on both morphological and metabolic state of the culture. Growth of mycelium is crucial for extracellular enzymes (8). Various physical and chemical factors have been known to affect the production of amylase such as temperature, $\mathrm{pH}$, carbon sources acting as inducers, and nitrogen sources respectively. Interactions of these parameters are reported to have a significant influence on the production of the enzyme (37).

\section{Effect of incubation temperature on amylase activity}

The amylase activity and the biomass were nil at lower $\left(15^{\circ} \mathrm{C}\right)$ and higher incubation $\left(45^{\circ} \mathrm{C}\right)$ temperature (results not shown). The optimum incubation temperature for amylase production was found to be at $30^{\circ} \mathrm{C}$ (Fig. 2.) and biomass also correlated with the results. The influence of temperature on amylase production is related to the growth of the organism. Hence, the optimum temperature for enzyme production depends on whether the culture is mesophilic or thermophilic. Among fungi, most of the amylase production studies have been done with mesophiles within the temperature range of 25 $37^{\circ} \mathrm{C}(17,28)$. Kundu and Das (22) and Ray (35) have reported that amylase activity was optimum at $30^{\circ} \mathrm{C}$ in Aspergillus oryzae, Botryodiplodia theobromae and Rhizopus oryzae. A raw starch degrading $\alpha$-amylase was also produced by $A$. ficuum at $30^{\circ} \mathrm{C}$ (19). Kathiresan and Manivannan (20) also reported $30^{\circ} \mathrm{C}$ as optimum temperature in case of Penicillium fellutanum isolated from mangrove rhizosphere soil. 


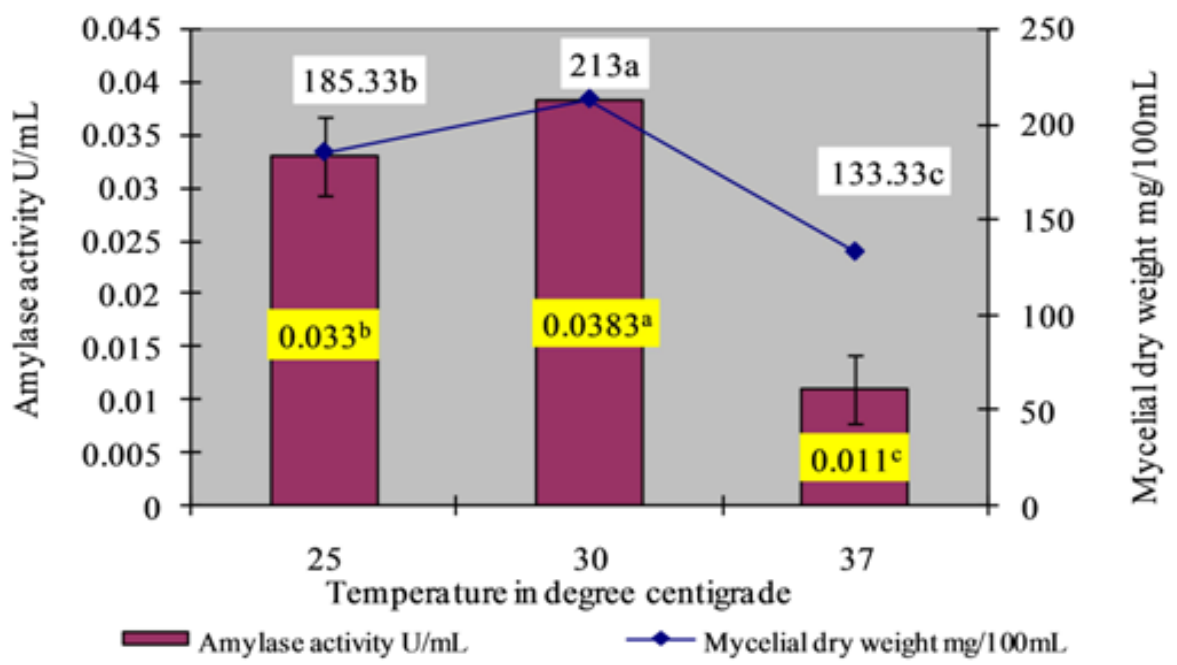

Figure 2. Effect of temperature on amylase production. The mean values followed by the same letter are not significantly different according to DMRT at $\mathrm{p}=0.05$.

\section{Effect of pH of the culture media on amylase activity}

The $\mathrm{pH}$ is one of the important factors that determine the growth and morphology of microorganisms as they are sensitive to the concentration of hydrogen ions present in the medium. The $\mathrm{pH}$ is known to affect the secretion of $\alpha$-amylase and its stability (18). The optimum $\mathrm{pH}$ for amylase production was 7.0 (Fig.3.), which is similar to the findings of Patel et al.,
(32) who reported in A. oryzae. The biomass yield was found to be higher in case of $\mathrm{pH} 5.0$ contradictory to the findings of Olama and Sabry (29) where the amylase activity and the biomass yield was maximum at $\mathrm{pH} 7.0$ in Aspergillus flavus and P. purpurescence. Aspergillus oryzae, A. ficuum and A. niger were found to give significant yields of $\alpha$-amylase between $\mathrm{pH}$ 5.0-6.0. $(9,12,19)$.

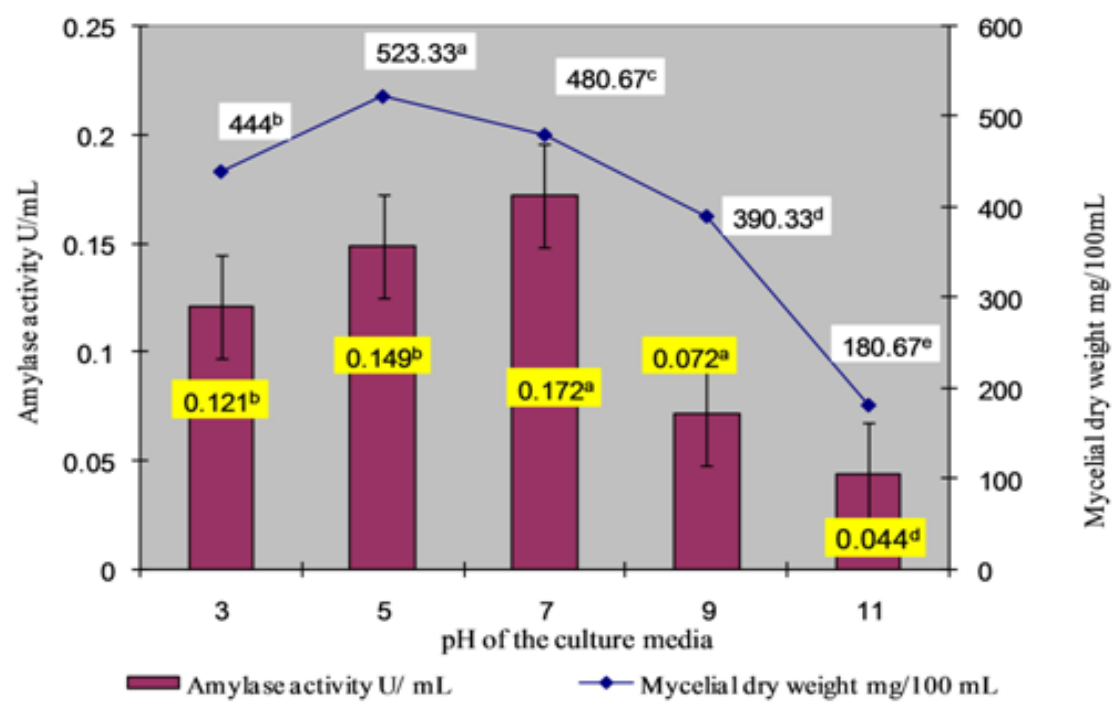

Figure 3. Effect of $\mathrm{pH}$ on amylase production. The mean values followed by the same letter are not significantly different according to DMRT at $\mathrm{p}=0.05$. 


\section{Effect of different carbon sources on amylase production}

The fungus was able to grow on all the tested carbon sources. There were significant differences in the yield of the biomass and amylase production. Among the various substrates screened for amylase production, maltose gave the highest enzyme activity followed by starch. The order of usability of substrate was maltose $>$ starch $>$ wheat bran powder $>$ corn flour $>$ cassava flour $>$ rice bran powder (Fig.4.). There was high increase in biomass yield in case of wheat bran powder and rice bran powder, but the enzyme activity was low in contrast to the findings of Ellaiah et al., (14) where amylase activity was maximum in Aspergillus spp. This indicates that the nature and amount of carbon source in culture media is important for the biomass growth and production of extracellular amylase.

Among chemical parameters, carbon source of the growth medium plays a very important role in inducing enzyme secretion. Amylase is generally induced in the presence of carbon sources such as starch and its hydrolytic products. Similarly, such findings were reported by Kathiresan and Manivannan (20) as maltose as best carbon source to enhance the amylase activity in $P$. fellutanum. Compared to defined carbon sources, the biomass yield was higher in undefined carbon sources similar to the findings of Oliveira et al., (30) in case of Rhizobial strains. Kuo and Hartman (23) showed that Thermoactinomyces vulgaris produces best yields of $\alpha$-amylase when starch or maltose is used as carbon source.

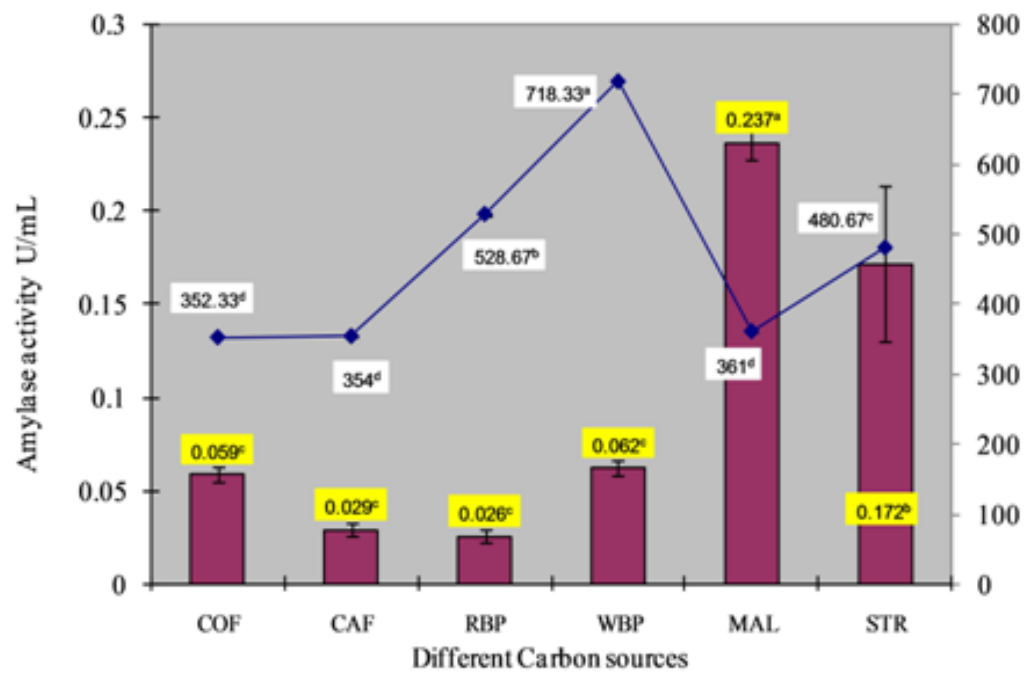

$$
\text { ह }
$$

Figure 4. Effect of different carbon sources on amylase production. The mean values followed by the same letter are not significantly different according to DMRT at $\mathrm{p}=0.05$.

\section{Effect of various nitrogen sources on amylase production}

Nitrogen sources have been reported to have an inducing effect on the production of various enzymes including $\alpha$-amylase in $\operatorname{SSF}$ system $(1,33,34)$. Earlier reports show that among various inorganic nitrogen sources tested, ammonium sulphate, ammonium chloride and ammonium hydrogen phosphate favored growth and enzyme secretion (28). Similar observations were recorded by Chandra et al., (11) Babu and Satyanarayana (2).
However, in our studies, there was no significant increase in enzyme yield in the case of the supplementation with either inorganic or organic nitrogen sources (Fig.5.). A marginal increase in amylase activity was noted with the addition of Sodium nitrate. A minimum activity was observed when Ammonium nitrate was used as nitrogen source. There was no significant difference in amylase activity with peptone, tryptone and beef extract indicating that any of these sources can be alternatively used. 


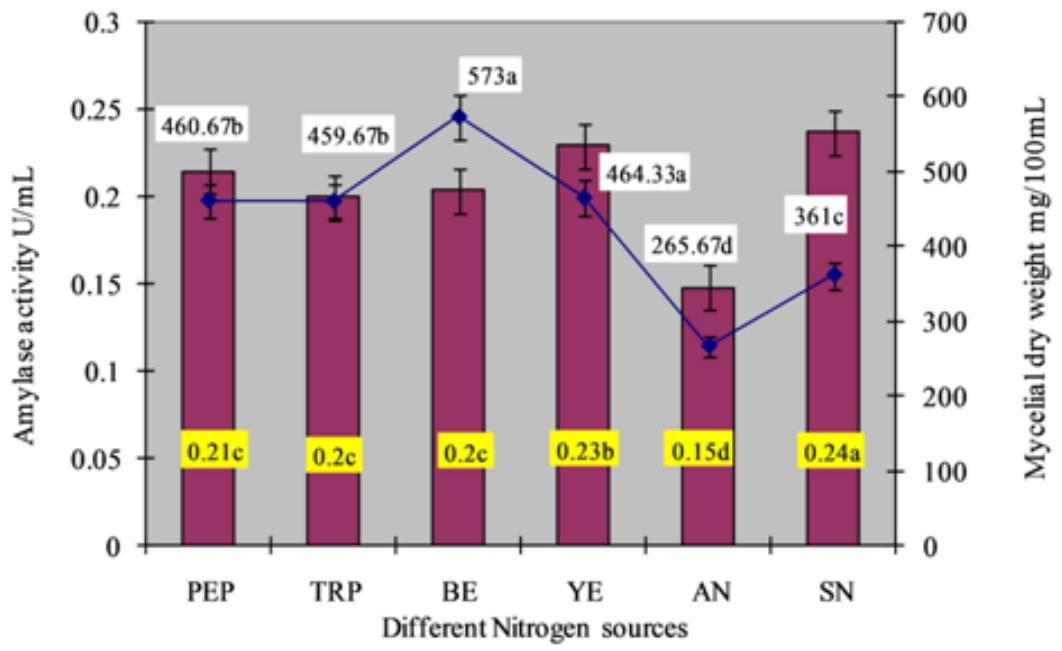

Amylase activity U/ mL $\longrightarrow$ Mycelial Dry weight $\mathrm{mg} / 100 \mathrm{~mL}$

Figure 5. Effect of different nitrogen sources on amylase production. The mean values followed by the same letter are not significantly different according to DMRT at $\mathrm{p}=0.05$.

\section{CONCLUSION}

In the present study, an attempt has been made to offer an endophytic fungus as source of enzymes for industrial requirements. The growth parameter of Cylindrocepahalum sp. for the maximum amylase production has been standardized, which can effectively be used in large scale production. Though, the cheaper agricultural byproducts are feasible for the production of amylase enzyme, but are not significant to the maltose when used as substrate. However, more detailed investigation is required to characterize this enzyme, which may be used in the large-scale production for commercial purpose in future.

\section{ACKNOWLEDGEMENTS}

The authors are thankful to Dr. Siddamallaya for authenticating the plant sample and maintaining the herbarium in National Ayurveda Dietetics Research Institute. (Central Council for Research in Ayurveda and Siddha, Department of AYUSH, Ministry of Health and F. W. Govt. of India, New Delhi) Jayanagar, Bangalore.

\section{REFERENCES}

1. Akher, M.; Leithy, M.A.; Massafy, M.K.; Kasim, S.A. (1973). Optimal conditions of the production of bacterial amylase. ZentralblBakteriol. Parasitenk. Infektionskr. Hyg., 128, 483-490.

2. Babu, K.R.; Satyanarayana, T. (1995). $\alpha$-Amylase production by thermophilic Bacillus coagulans in solid state fermentation. Process Biochem., 30, 305-309.

3. Barnett, H. L.; Barry Hunter, B. (1998). Illustrated genera of imperfect fungi, fourth edition. American Phytopathological Society.

4. Bills, G.; Polishook, J. D. (1991). Microfungi from Carpinius carloliniana. Can. J. Bot., 69, 1477-1482.

5. Bordbar, A.K.; Omidiyan. K. R.; Hosseinzadeh. (2005). Study on interaction of $\alpha$ - amylase from Bacillus subtilis with cetyltrimethylammoniumbromide. Colloids Surf. B: Biointerfaces., 40, $67-71$.

6. Burhan, A.; Nisa. U.; Gokhan. C.; Omer. C.; Ashabil. A.; Osman. G. (2003). Enzymatic properties of a novel thermostable, thermophilic, alkaline and chelator resistant amylase from an alkalophilic Bacillus sp. isolate ANT-6. Process. Biochem., 38, 1397-1403.

7. Caldwell, B.A.; Jumpponen, A.; Trappe, J.M. (2000). Utilization of major detrital substrates by dark septate, root endophytes. Mycologia., 92: $230-232$.

8. Carlsen, M.; Nielsen. J.; Villadsen, J. (1996 a). Growth and $\alpha$-amylase production by Aspergillus oryzae during continuous cultivations. J. Biotechnol., 45, 81-93.

9. Carlsen, M.; Spohr. A.B.; Nielsen. J.; Villadsen. J. (1996 b). 
Morphology and physiology of a $\alpha$-amylase producing strain of Aspergillus oryzae during batch cultivations. Biotechnol.Bioeng.,49, 266-276.

10. Carroll, G. (1988). Fungal endophytes in stems and leaves: From latent pathogen to mutualistic pathogen. Ecol.soci. Am., 69(1), 2-9

11. Chandra, A.K.; Medda, S.; Bhadra, A.K. (1980). Production of extracellular thermostable $\alpha$-amylase by Bacillus licheniformis. $J$. Ferment. Technol., 58, 1-10.

12. Djekrif-Dakhmouche, S.; Gheribi-Aoulmi, Z.; Meraihi, Z.; Bennamoun, L. (2005). Application of a statistical design to the optimization of culture medium for $\alpha$-amylase production by Aspergillus niger ATCC 16404 grown on orange waste powder. J. Food Eng., 73,190-197.

13. Duncan, D.B. (1955). Multiple range and multiple $F$-tests. Biometrics., $11,1-42$.

14. Ellaiah, P.; Adinarayana, K.; Bhavani, Y.; Padmaja, P.; Srinivasulu, B. (2002). Optimization of process parmeter for glucoamylase production under solid state fermentation by a newly isolated Aspergillus species. Process. Biochem., 38, 615-620.

15. Ellis, M.B. (1971). Dematiaceous Hyphomycetes. Commonwealth Mycological Institute, Kew, Surrey, England.

16. Fisher, P.J.; Pertini, O.; Sutton, B.C. (1993). A comparative study of fungal endophytes in xylem and bark of Eucalyptus niters in Australia and England. Sydowia., Vol. 45.

17. Francis, F.; Sabu, A.; Nampoothiri, K.M.; Ramachandran, S.; Ghosh, S.; Szakacs, G.; Pandey, A. (2003). Use of response surface methodology for optimizing process parameters for the production of $\alpha$-amylase by Aspergillus oryzae. Biochem. Eng. J., 15, 107-115.

18. Fogarty, W.M. (1983). Microbial Amylases. In Microbial Enzymes and Biotechnology. (eds). Fogarty,W.M. Applied Science Publishers Ltd., London, UK p. 1-92.

19. Hayashida, S.; Teramoto, Y. (1986). Production and characteristics of raw starch digesting $\alpha$-amylase from a protease negative Aspergillus ficuum mutant. Appl. Environ. Microbiol., 52, 1068-1073.

20. Kathiresan, K.; Manivannan, S. (2006). $\alpha$-Amylase production by Penicillium fellutanum isolated from mangrove rhizosphere soil. Afr. J. Biotechnol., 5, 829-832.

21. Khajeh, K.; Shokri, M.M.; Asghan, S.M.; Moradian, F.; Ghasemi, A. (2006). Acidic proteolytic digestion of $\alpha$-amylase from Bacillus licheniformis and Bacillus amyloliquefaciens: Stability and flexibility analysis. Enzyme Microbial. Technol., 38, 422-428.

22. Kundu, A.K.; Das, S. (1970). Production of amylase in liquid culture by a strain of Aspergillus oryzae. Appl. Microbiol., 19(4), 598-603.

23. Kuo, M.J.; Hartman, P.A. (1966). Isolation of amylolytic strains of Thermoactinomyces vulgaris actinomycte amylases. J. Bacteriol., 92, 723-726.

24. Maria, G.L.; Sridhar, K.R.; Raviraj, N.S. (2005). Antimicrobial and enzyme activity of mangrove endophytic fungi of southwest coast of
India. J. Agric. Technol., 1: XX, 67-80.

25. Mariana Recco, P. Molina, G.; Dion'1sio,. Dion'1sio, A.P.; Mar'ostica Junior, M.R.; Pastore, G. M. (2011). The Use of Endophytes to Obtain Bioactive Compounds and Their Application in Biotransformation Process. Electronic journal of Biotechnology Research International. Available in http://www.hindawi.com/journals/btri/2011/576286/

26. Marlida, Y.; Saari. N.; Hassan, Z.; Radu, S. (2000). Raw Starch degrading enzyme from isolated strains of endophytic fungi. World $J$. Microbiol. Biotechnol., 16: 573-578.

27. Miller, G.L. (1959). Use of dinitrosalicyclic acid reagent for determination of reducing sugar. Anal Chem., 31, 426-429.

28. Narang, S.; Satyanarayana, T. (2001). Thermostable $\alpha$-amylase production by an extreme thermopile Bacillus thermooleovorans. Lett. Appl. Microbiol., 32, 31-35.

29. Olama, Z.; Sabry, A. (1989). Extracellular amylase synthesis by Aspergillus flavus and Penicillium purpurescense. J. of Islamic Aca. Sci., 24, 272-276.

30. Oliveira, A.N.; Oliveira, L.A.; Andrade, J.S.; A.F.C. Júnior. (2007). Rhizobial amylase production using various starchy substances as carbon substrates. Braz. J. Microbiol., 38, 208-216.

31. Pandey, A.; Nigam, P.; Soccol. C.R.; Soccol, V.T.; Singh, D.; Mohan, R. (2000). Advances in microbial amylases. Biotechnol. Appl. Biochem., 31, 135-152.

32. Patel, A. K.; Nampoothiri, K.M.; Ramchandran, S.; Szakacs, G.; Pandey, A. (2005). Partial purification and characterization of alpha amylase produced by Aspergillus oryzae using spent brewing grains. Indian J. Biotechnol., 4, 336-341.

33. Pedersen, H.; Nielsen, J. (2000). The influence of nitrogen sources on the $\alpha$-amylase productivity of Aspergillus oryzae in continuous cultures. Appl. Microbiol. Biotechnol., 53, 278-281.

34. Rahardjo, Y.S.P.; Sie, S.; Weber, F.J.; Tramper, J.; Rinzema, A. (2005). Effect of low oxygen concentrations on growth and $\alpha$-amylase production of Aspergillus oryzae in model solid-state fermentation systems. Biomol. Eng., 21, 163-172.

35. Ray, R.C. (2004). Extracellular amylase(s) production by fungi Botryodiplodia theobromae and Rhizopus oryzae grown on Cassava starch residue. J. of Environ. Biol., 25(4), 489-95.

36. Satyanarayana, T.; Rao, J.L.U.M.; Ezhilvannan, M.; $\alpha$-Amylases. (2005). In:Enzyme Technol,, A. Pandey, C. Webb, C.R. Soccol, C. Larroche. (eds). Asia tech Publishers Inc., New Delhi, India, p. 189-220.

37. Shivaramkrishnan. S.; Gangadharan, D.; Nampoothiri, K.M.; Soccol, C. R.; Pandey, A. (2006). $\alpha$-Amylases from Microbial Sources. Food Technol. Biotechnol., 44 (2), 173-184.

38. Sutton, B.C. (1971). The Coelomycetes: Fungal imperfecti with pycnidia, acervuli and stoma. Commonwealth Mycological Institute, Surrey, England.

39. Tanyildizi, M.S.; Ozer, D.; Elibol, M. (2005). Optimization of $\alpha$ - 
amylase production by Bacillus sp. using response surface methodology. Process Biochem., 40, 2291-2296.

40. Vander Maarel, M.J.E.C.; van der Veen, B.; Uitdehaag, J.C.M.;
Leemhuis, H.; Dijkhuizen, L. (2002). Properties and applications of starch-converting enzymes of the $\alpha$-amylase family. J. Biotechnol., 94, $137-155$.

\section{(cc) BY-NC}

All the content of the journal, except where otherwise noted, is licensed under a Creative Commons License 